\title{
Megalocytivirus infection in orbiculate batfish Platax orbicularis
}

\author{
Preeyanan Sriwanayos ${ }^{1}$, Ruth Francis-Floyd ${ }^{1,2}$, Mark F. Stidworthy ${ }^{3}$, \\ Barbara D. Petty ${ }^{1,2}$, Karen Kelley ${ }^{4}$, Thomas B. Waltzek ${ }^{5, *}$
}

${ }^{1}$ Program in Fisheries and Aquatic Sciences, School of Forestry Resources and Conservation, University of Florida, Gainesville, Florida 32653, USA

${ }^{2}$ Department of Large Animal Clinical Sciences, College of Veterinary Medicine, University of Florida, Gainesville, Florida 32610, USA

${ }^{3}$ International Zoo Veterinary Group, Station House, Parkwood Street, Keighley, West Yorkshire BD21 4NQ, UK

${ }^{4}$ Interdisciplinary Center for Biotechnology Research (ICBR), Cellomics Division, Electron Microscopy and Bio-imaging Core Laboratory, University of Florida, Gainesville, Florida 32611, USA

${ }^{5}$ Department of Infectious Diseases and Pathology, College of Veterinary Medicine, University of Florida, Gainesville, Florida 32608, USA

\begin{abstract}
Megalocytiviruses cause systemic disease in both marine and freshwater fishes, negatively impacting ornamental and food fish aquaculture. In this report, we characterize a megalocytivirus infection in a captive marine ornamental fish, the orbiculate batfish Platax orbicularis. Histologic examination revealed cytomegalic cells characterized by strongly basophilic granular intracytoplasmic inclusions within various organs. Transmission electron microscopy revealed icosahedral virus particles within the cytoplasm of cytomegalic cells consistent with an iridovirus infection. Analysis of the major capsid protein gene sequence confirmed that the orbiculate batfish virus is a member of the family Iridoviridae and is identical to the only other megalocytivirus reported from a marine ornamental fish, the Banggai cardinalfish Pterapogon kauderni iridovirus.
\end{abstract}

KEY WORDS: Iridovirus · Megalocytivirus · Orbiculate batfish $\cdot$ Phylogeny

\section{INTRODUCTION}

Iridoviruses have been identified from various species of fishes and are important problems for aquaculture industries (Ahne et al. 1997, Rodger et al. 1997, He et al. 2000, Paperna et al. 2001, Wang et al. 2003, Shi et al. 2004, Wang et al. 2011). Members of the family Iridoviridae infect a range of poikilothermic hosts, including invertebrates, fish, amphibians, and reptiles (Chinchar et al. 2009). The family is organized into 5 genera, Iridovirus, Chloriridovirus, Ranavirus, Megalocytivirus, and Lymphocystivirus; the latter 3 genera infect fishes. Megalocytiviruses are large, double-stranded DNA viruses with an icosahedral capsid (Kurita \& Nakajima 2012). Members of the genus Megalocytivirus are pathogenic to a wide variety of freshwater and marine fishes, and have had a negative impact on ornamental and food fish aquaculture worldwide (Armstrong \& Ferguson 1989, Anderson et al. 1993, Fraser et al. 1993, Rodger et al. 1997, Sudthongkong et al. 2002, Gibson-Kueh et al. 2004, Jeong et al. 2008a,b, Chinchar et al. 2009, Weber et al. 2009, Kim et al. 2010, Yanong \& Waltzek 2010, Zhang et al. 2011). Megalocytiviruses induce lethal systemic disease at water temperatures ranging from 7.5 to $32^{\circ} \mathrm{C}\left(45.5\right.$ to $89.6^{\circ} \mathrm{F}$ ) (Chen et al. 2003, 
Yanong \& Waltzek 2010, Wang et al. 2011, Zhang et al. 2011, Waltzek et al. 2012). Epizootics may result in up to $100 \%$ mortality under intensive aquaculture conditions (Fraser et al. 1993, Rodger et al. 1997, He et al. 2000, Sudthongkong et al. 2002). These viruses can spread horizontally from fish to fish by cohabitation, exposure to water or equipment carrying the virus, and ingestion of infected fish or feed items (He et al. 2002, Go \& Whittington 2006, Yanong \& Waltzek 2010).

Megalocytivirus-infected fish may exhibit nonspecific clinical signs including lethargy, anorexia, hyperpigmentation, exophthalmos, skin lesions, unusual swimming behavior, severe anemia, and white feces (Chen et al. 2003, Weber et al. 2009, Wang et al. 2011, Waltzek et al. 2012). On post-mortem examination, fish infected with megalocytiviruses may exhibit hemorrhagic lesions, renomegaly, splenomegaly, hepatomegaly, and coelomic distension resulting from hemorrhagic fluid accumulation (Chen et al. 2003, Weber et al. 2009, Yanong \& Waltzek 2010, Wang et al. 2011, Zhang et al. 2011, Waltzek et al. 2012). Histopathologic examination typically reveals cytomegalic mesenchymal cells characterized by strongly basophilic or amphophilic granular intracytoplasmic inclusions observed in multiple organs including the spleen, kidney, liver, heart, brain, gills, intestine, eyes, and gonads (Chen et al. 2003, Gibson-Kueh et al. 2003, Weber et al. 2009, Yanong \& Waltzek 2010, Zhang et al. 2011, Waltzek et al. 2012). Transmission electron microscopy (TEM) invariably reveals numerous icosahedral virus particles with a capsid diameter between 120 and $200 \mathrm{~nm}$ in the cytoplasm of infected cells (Chen et al. 2003, Weber et al. 2009, Yanong \& Waltzek 2010, Wang et al. 2011, Zhang et al. 2011, Kurita \& Nakajima 2012, Waltzek et al. 2012).

Phylogenetic analyses support 4 separate species within the genus Megalocytivirus (Kurita \& Nakajima 2012, Waltzek et al. 2012). Megalocytiviruses related to red sea bream iridovirus (RSIV) cluster into 1 of 2 genotypes and have been associated with mass mortality epizootics in more than 30 maricultured species in Japan, Korea, China, and Southeast Asia (Inouye et al. 1992, Jung \& Oh 2000, Kawakami \& Nakajima 2002, Wang et al. 2003). Infectious spleen and kidney necrosis virus (ISKNV), originally isolated from mandarin fish Siniperca chuatsi raised for food in China, has also resulted in epizootics in more than 10 species of freshwater ornamental fishes (He et al. 2000, Paperna et al. 2001, Sudthongkong et al. 2002, Yanong \& Waltzek 2010). A second ISKNV geno- type was recently recognized following disease episodes in ornamental and food fish species (Kurita \& Nakajima 2012), which included Banggai cardinalfish iridovirus (BCIV) isolated from a marine ornamental species (Banggai cardinalfish Pterapogon kauderni) and marbled sleepy goby iridovirus (MSGIV) isolated from a freshwater species (marbled sleeper goby Oxyeleotris marmorata) cultured for food in China (Weber et al. 2009, Wang et al. 2011). The third species, turbot reddish body iridovirus (TRBIV), has primarily been associated with disease in a cultured Asian flatfish species, the turbot Scophthalmus maximus (Shi et al. 2004). A fourth megalocytivirus species was recently proposed, threespine stickleback iridovirus (TSIV), from an epizootic that occurred in a Canadian collection of threespine stickleback Gasterosteus aculeatus (Waltzek et al. 2012).

Orbiculate batfish Platax orbicularis are tropical marine ornamental species belonging to the order Perciformes, family Ephippidae. They can be found throughout the Western Indo-Pacific region (Capuli \& Ortanez 2011). Orbiculate batfish occur in a variety of habitats: mangroves in shallow coastal waters, other sheltered waters, deep seaweed reefs, and open waters. They prefer water temperatures ranging from 22 to $28^{\circ} \mathrm{C}\left(71.7\right.$ to $82.4^{\circ} \mathrm{F}$ ) (Capuli \& Ortanez 2011). Orbiculate batfish have only recently been successfully bred in captivity, and thus information regarding viral diseases in this species is limited (David et al. 2010). Only 2 viral infections, lymphocystis and betanodavirus, have previously been reported in P. orbicularis (Lawler et al. 1978, David et al. 2010).

In the present study, we report a megalocytivirus infection in Platax orbicularis that was associated with mortality in recently imported wild-caught fish acquired by a public aquarium in Belgium. The objective of this study was to compare clinical aspects of the disease as well as microscopic and ultrastructural features of the virus with previously described megalocytiviruses, including the virus associated with the only other marine ornamental epizootic reported in Banggai cardinalfish.

\section{MATERIALS AND METHODS}

\section{Clinical history}

A mortality event occurred in March 2010 among a group of 10 orbiculate batfish quarantined at a public aquarium in Belgium. These wild-caught juvenile 
orbiculate batfish (average of $12 \mathrm{~cm}$ in total length) from Indonesia had been purchased by an ornamental fish import facility in the UK and sent to a quarantine facility in the UK, where they were acclimatized and quarantined prior to delivery to the aquarium in Belgium in February 2010. At the aquarium, the batfish were maintained in a quarantine system equipped with an external power filter. Water quality parameters were maintained at a temperature of $24^{\circ} \mathrm{C}\left(75^{\circ} \mathrm{F}\right), \mathrm{pH} 7.8$, nitrite $<0.3 \mathrm{mg} \mathrm{l}^{-1}$, nitrate 0 to $12.5 \mathrm{mg} \mathrm{l}^{-1}$, salinity $32,96 \%$ oxygen saturation, and undetectable total ammonia nitrogen. The orbiculate batfish were fed mysid (Mysidopsis) and brine shrimp (Artemia) 5 to 6 times per day.

On arrival, several fish had moderately frayed fins. Two days after arrival, one fish became anorexic, displayed an increased respiration rate, and was noticeably darker than other batfish in the same tank. A wet mount examination of skin mucus of this batfish was negative for parasites. This fish was dipped in

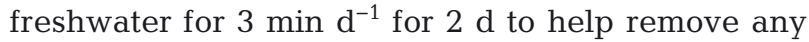
parasites not detected by wet mount examination. All fish in the same tank were treated with a formalin bath at $100 \mathrm{mg} \mathrm{l}^{-1}$ for $6 \mathrm{~h}$ to control a suspected parasite infection. Fish were also treated prophylactically with an oxytetracycline (Aquatet ${ }^{\circledR}$, PHARMAQ) bath at $100 \mathrm{mg} \mathrm{l}^{-1}$ daily for $7 \mathrm{~d}$. Mortality began during the treatment and a total of 8 fish died during the $4 \mathrm{wk}$ quarantine period. Gross necropsy findings were unremarkable; however, fleshy white nodules were noted on the dorsal fins of all fish that died and were also observed on the remaining 2 fish in the tank. Following necropsy, specimens were fixed in $10 \%$ neutral buffered formalin and sent to the International Zoo Veterinary Group (IZVG) Pathology Laboratory, UK, for histological processing and examination.

\section{Histopathology}

For 2 separate formalin-fixed fish that had been necropsied, 5 transverse sections and 1 sagittal section of the head were cut and dehydrated through a series of water and alcohol mixtures to full alcohol. Tissues were then cleared through a clearant and embedded into paraffin blocks ( 2 blocks per individual). The 4 paraffin blocks were sectioned at $3 \mu \mathrm{m}$, mounted onto glass slides, and stained with hematoxylin and eosin (H\&E). In addition to examination by IZVG Pathology Laboratory, these blocks were also submitted to the University of Florida Marine Animal Disease Laboratory, Gainesville, FL, USA.

\section{Transmission electron microscopy}

One paraffin block was selected by evaluating an H\&E-stained slide for features consistent with megalocytivirus pathology. Heart tissue was selected from this block for TEM evaluation and sent to the Electron Microscopy Laboratory (EML), Department of Medical Pathology and Laboratory Medicine, School of Medicine, University of California at Davis. An area with characteristic megalocytivirus pathology in the heart was removed from the paraffin block and placed in $100 \%$ xylene; after clearing overnight, the tissue was rehydrated and processed using a standard protocol (Johannessen 1977) as previously described (Hayat 1989). Ultrathin sections (45 to $60 \mathrm{~nm}$ ) were post-stained with $2 \%$ aqueous uranyl acetate followed by Reynold's lead citrate and examined using a transmission electron microscope at the EML. These samples were also examined with an electron microscope at the University of Florida Electron Microscopy and Bio-imaging Laboratory.

\section{DNA extraction, PCR amplification, and sequencing}

At the University of Florida Marine Animal Disease Laboratory, DNA was extracted from $50 \mu \mathrm{m}$ sections of formalin-fixed, paraffin-embedded tissues using a commercial extraction kit (DNeasy ${ }^{\circledR}$ Blood and Tissue Kit, Qiagen) following the manufacturer's instructions for paraffin-embedded tissues. PCR amplification of the viral full-length major capsid protein (MCP) gene sequence was performed using 14 primer pairs designed from the complete MCP gene sequence of BCIV (which is also known as the Pterapogon kauderni iridovirus or PkIV; GenBank accession no. AB669096.1) (Table 1).

The $20 \mu \mathrm{l}$ PCR mixtures consisted of $0.1 \mu$ l of Platinum Taq DNA Polymerase (Invitrogen), $2.0 \mu \mathrm{l}$ of $10 \times$ PCR buffer, $0.8 \mu \mathrm{l}$ of $50 \mathrm{mM} \mathrm{MgCl}_{2}, 0.4 \mu \mathrm{l}$ of $10 \mathrm{mM}$ dNTPs, $1.0 \mu \mathrm{l}$ of $20 \mu \mathrm{M}$ of forward and reverse primers, $11.7 \mu \mathrm{l}$ of molecular grade water, and $3 \mu \mathrm{l}$ of DNA template. The PCR conditions used for all reactions included an initial denaturation of $5 \mathrm{~min}$ at $95^{\circ} \mathrm{C}$, followed by 50 cycles of denaturation at $95^{\circ} \mathrm{C}$ for $1 \mathrm{~min}$, annealing at $50^{\circ} \mathrm{C}$ for $1 \mathrm{~min}$, and extension at $72^{\circ} \mathrm{C}$ for $1 \mathrm{~min}$, followed by a final elongation step at $72^{\circ} \mathrm{C}$ for $10 \mathrm{~min}$. After electrophoresis, bands were gel extracted using a QIAquick gel extraction kit (Qiagen). Purified DNA fragments were then submitted to the University of Florida Interdisciplinary Center for Biotechnology Research for sequencing on ABI 3130 DNA sequencers (Applied Biosystems). 
Table 1. Primers used to amplify fragments of the major capsid protein gene sequence from the orbiculate batfish iridovirus (OBIV). Note that amplicon size includes primers

\begin{tabular}{|c|c|c|c|}
\hline Primer & Orientation & Sequence $\left(5^{\prime}-3^{\prime}\right)$ & $\begin{array}{l}\text { Amplicon } \\
\text { size (bp) }\end{array}$ \\
\hline MCPF1 & Forward & CTGTTGGTCTTGCTGAGTGC & 158 \\
\hline BeginR & Reverse & CCGTACAAGTGGGTCTCCAT & \\
\hline Angelnew1F & Forward & GTTCATCGACATCTCCGCGT & 177 \\
\hline Angelmcp1R & Reverse & GCCACCGTGACACTAAACTC & \\
\hline Angelmcp2fb & Forward & GGGGTGGCGACTACCTCATT & 194 \\
\hline Angelmcp2R & Reverse & CCAGGTCGTTAAATGACACCG & \\
\hline Angelmcp3F & Forward & CAGCTACATTCGCTGGTGCGAC & 150 \\
\hline Angelmcp3R & Reverse & GCATGCCAATCATCTTGT & \\
\hline SmallgapF & Forward & CTGGAACGCCTGCATGAT & 124 \\
\hline SmallgapR & Reverse & ATAGTCTGGCCGTTGGTGAT & \\
\hline MegalofixedF & Forward & ACAAGATGATTGGCATGCG & 166 \\
\hline MegalofixedR & Reverse & TTGAAGTGGATGCGCACCT & \\
\hline Biggap1Fa & Forward & GGCGTTGCCTACTGTGTCTC & 163 \\
\hline Big1Ra & Reverse & CAGGGTGACGGTTGATATGG & \\
\hline Biggap1Fb & Forward & GGACCTGCTCATCAGCCAGAG & 165 \\
\hline Angelnew1R & Reverse & CTACGACTAGACTGGGCCA & \\
\hline Angelnew2F & Forward & CTGACAAGCGAGGAGCGTG & 214 \\
\hline Angelnew2R & Reverse & GGGGACTGGCCGCGGTGTAG & \\
\hline Angelnew3F & Forward & TCACCCACCGCAACGTGC & 188 \\
\hline Angelnew3R & Reverse & GGGCGCAAAGTAGTAGG & \\
\hline Biggap2Fa & Forward & GCTCCACCAGATGGGAGTAG & 153 \\
\hline Biggap2Ra & Reverse & GACAGGCGGCCGTAGTTG & \\
\hline Biggap2Fb & Forward & GGACATGGGCAATATCAACC & 132 \\
\hline Biggap2Rb & Reverse & GTGTAGCCGGAGCCGTTG & \\
\hline Angelnew5F & Forward & GGACAATGCAAAGACCA & 145 \\
\hline ISKNVMCPF & Reverse & TTACAGGATAGGGAAGCCTGC & \\
\hline EndF & Forward & GGTCAAGTTTGAAAACCCGA & 121 \\
\hline MCPR4 & Reverse & CATAGCTACCAGACACACGG & \\
\hline
\end{tabular}

being available for certain important taxa. The aligned data set was imported into jModelTest version 0.1.1 (Guindon \& Gascuel 2003, Posada 2008) and Akaike's information criterion was used to select a best-fit model of evolution for phylogenetic analysis. Maximum likelihood analyses were conducted using MEGA version 5 (Tamura et al. 2011) with 1000 bootstrap replicates selected for determining node support.

\section{RESULTS}

\section{Histopathology}

Histopathologic examination revealed multiple areas of necrosis with pyknotic and karyorrhectic cellular debris in the renal hematopoietic tissue (with occasional associated minimal epithelial necrosis) (Fig. 1A), liver, and spleen. Numerous cytomegalic cells containing granular basophilic intracytoplasmic inclusions were commonly observed in the renal interstitium and glomeruli of both specimens (Fig. 1A). Similar cyto-

\section{BLASTN, molecular data set, sequence alignment, and phylogenetic analysis}

Following sequence assembly and removal of primer sequences, general BLASTN searches (www. ncbi.nlm.nih.gov/blast/Blast.cgi) of the full-length viral MCP gene sequence were conducted (Altschul et al. 1997). Megalocytiviral taxa identified by these analyses were combined with taxa from recent comprehensive phylogenetic analyses (Kurita \& Nakajima 2012, Waltzek et al. 2012) to build the final data set. Sequence alignments were performed using Mafft 5.8 (Katoh et al. 2005) followed by minor manual adjustments in ClustalW (Thompson et al. 1994). The E-INS-I alignment strategy was used with the following parameters: scoring matrix BLOSUM62, a gap open penalty of 1.53, and an offset value of 0 . The final aligned data set was trimmed to the first conserved nucleic acid at the $3^{\prime}$ end of the MCP sequence due to incomplete data megaly with associated inclusions were also observed within the spleen, liver, gill lamellae (Fig. 1B), lamina propria and submucosa of the esophagus, stomach (Fig. 1C), intestine, and heart (Fig. 1D).

\section{Transmission electron microscopy}

TEM revealed numerous icosahedral virus particles arranged in paracrystalline arrays consistent with an iridovirus within the cytoplasm of enlarged cardiac myocytes (Fig. 2). The observed viral assembly sites appeared to disrupt the myocyte myofibrils (Fig. 2B). Virus particles were naked with an electron-dense nucleic acid core surrounded by a translucent zone and an outer nucleocapsid layer (Fig. 2C,D). The mean diameter of virus particles, measured from apex to apex, was $158 \mathrm{~nm} \mathrm{(n} \mathrm{=} \mathrm{50,}$ $\mathrm{SD}=7.5 \mathrm{~nm})$, and from side to side was $128 \mathrm{~nm}(\mathrm{n}=$ $50, \mathrm{SD}=5.6 \mathrm{~nm})$. 

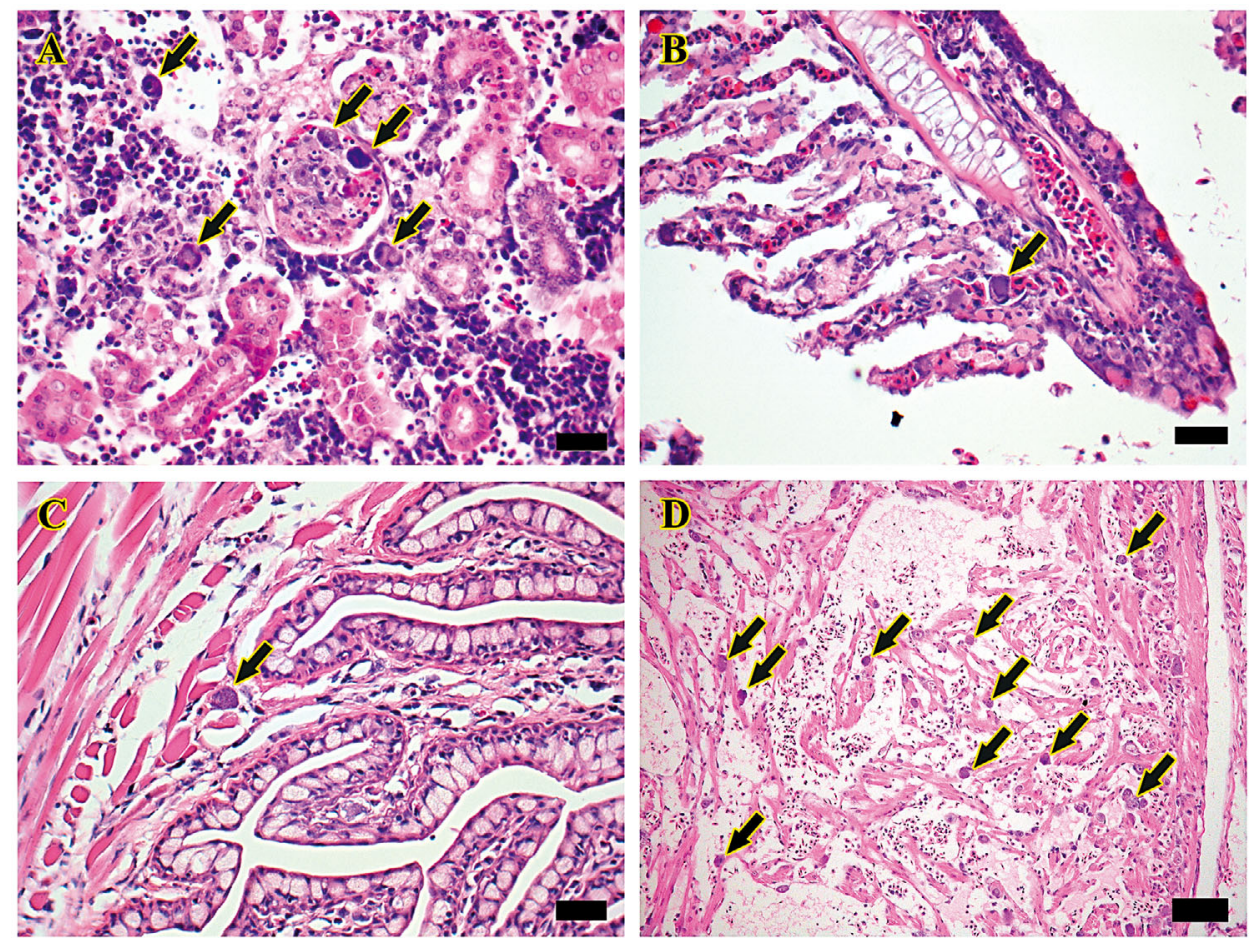

Fig. 1. Platax orbicularis. Intracytoplasmic basophilic inclusions (arrows) in infected orbiculate batfish. H\&E stain. (A) Interstitium and glomeruli of kidney. Scale bar $=20 \mu \mathrm{m}$. (B) Secondary lamellae of gill. Scale bar $=20 \mu \mathrm{m}$. (C) Submucosa of stomach. Scale bar $=20 \mu \mathrm{m}$. (D) Heart. Scale bar $=50 \mu \mathrm{m}$
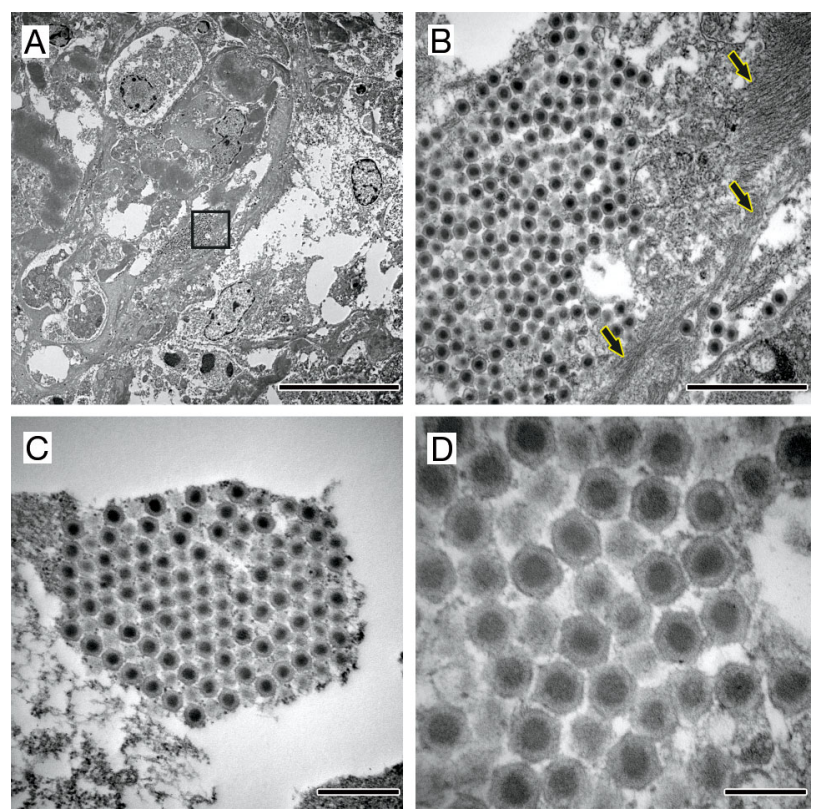

Fig. 2. Platax orbicularis. Transmission electron photomicrographs of iridoviral-infected cells in the heart of an orbiculate batfish. (A) Cluster of virus particles in the cytoplasm of an infected myocyte; black rectangle outlines area shown in (B). Scale bar $=10 \mu \mathrm{m}$. (B) Numerous virus particles disrupting myocyte myofibrils (arrows). Scale bar $=1 \mu \mathrm{m}$. (C) Virions arranged in a paracrystalline array. Scale bar $=500 \mathrm{~nm}$. (D) Higher magnification of (C) revealing the naked icosahedral virus shape and the electron-dense nucleic acid core surrounded by a pale zone and an outer nucleocapsid layer of moderate electron density. Scale bar $=200 \mathrm{~nm}$

\section{Sequencing, BLASTN, molecular data set, and phylogenetic analysis}

The sequenced PCR amplicons generated in this study ranged in size from 121 to $214 \mathrm{bp}$ (Table 1) and when assembled resulted in 1470 contiguous bp of the viral genome that contained the full-length MCP sequence (1362 bp; BankIt no. 1592328). The BLASTN search of the viral MCP sequence from the infected batfish revealed highest sequence identity with ISKNV genotype 2 megalocytiviruses, including BCIV (GenBank accession no. AB669096; 100\%) and MSGIV (GenBank accession no. HM067835; 99\%). The final aligned MCP data set after truncation of the $3^{\prime}$ end of the sequence contained 1357 nucleic acid characters for 90 taxa. jModelTest identified the TrN+G model to be the most suitable model for phylogenetic analyses.

The phylogenetic analysis of the MCP gene supported the recognition of 4 species within the genus Megalocytivirus (Fig. 3). The Maximum Likelihood analysis demonstrated with a high level of confidence that the identical virus from orbiculate batfish (hereafter referred to as the orbiculate batfish iridovirus, OBIV) and Banggai cardinalfish (BCIV) is the sister group to MSGIV. These 2 megalocytiviruses form the ISKNV genotype 2 clade (Fig. 3). 
Fig. 3. Phylogram depicting the relationship of the orbiculate batfish iridovirus (OBIV) to representatives from each of the 4 megalocytivirus species (red sea bream iridovirus [RSIV], infectious spleen and kidney necrosis virus [ISKNV], turbot reddish body iridovirus [TRBIV], and threespine stickleback iridovirus [TSIV]) in the family Iridoviridae, based on the sequence of the major capsid protein $(\mathrm{MCP} ; 1357$ nucleic acid characters including gaps). Numbers above or below each node represent bootstrap support of the maximum likelihood analysis (values $>80$ shown). Branch lengths are based on the number of inferred substitutions, as indicated by the scale. The red arrow shows the position of OBIV. Accession numbers, host, and location of isolation are listed for each operational taxonomic unit. *Note: OBIV and the Banggai cardinalfish iridovirus (BCIV, which is also known as the Pterapogon kauderni iridovirus or PkIV_AB669096_Banggai cardinalfish_Southeast Asia) were treated as a single taxon in the phylogenetic analysis given their identical MCP sequences
RSIV-3GG1_AB666326_orange-spotted_grouper_Hong_Kong -SFIV-724China_HQ263620_stone_flounder_China RSIV-8_AB666335_red_sea_bream_Japan RSIV-8Pe_AB666321_Japanese_sea_perch_Hong_Kong RSIV-5_AB666332_Japanese_sea_perch_Japan RBIV-KOR-TY4_AY532608_barred_knifejaw_Korea RSIV-2_AB666329 greater_amberjack_Japan RSIV-3_AB666330_pacific_bluefin_tuna_Japan RSIV-3_AB666330_pacific_bluefin_tuna_Japan
RSIV-TGA14_AB666320_brown_marbled_grouper_Singapo OSGIV_AY894343_orange-spotted_grouper_China RSIV-GIG45_AB666325_giant grouper_Hong_Kong _ GSIV-K1_EU315313_giant_grouper_Taiwan RSIV-10GG_AB666323 orange-spotted_grouper_Hong_Kong RSIV-9_AB666336_greater_amberjack_Japan SBIV-KOR-TY_AY532613_sea_bass_Korea RSIV-7GG_AB666322_orange-spotted_grouper_Hong_Kong RSIV-GIG42_AB666323_giant_grouper_Hong_Kong

RSIV-6 AB666333 Japanese amberjack Japan

85 [ ISKNV-HT_HQ317464_Japanese_amberjack_China ISKNV-HZhj_HQ317463_Japanese_amberjack_China 89 - OFIV2_DQ198145_bastard_halibut_Korea RBIV-CNU-1_AY849393_barred_knifejaw_Korea SKIV-ZJ07_GQ202216_spotted_knifejaw_China

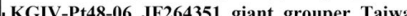
KGIV-Pt8-06_JW26435_giantgrouper_Taiwan [GSIV-Pt327-08_JF264346_giant_sea_perch_Tai -RSIV-0918_AY310918_red_sea_bream_Japan RSIV-KST-Y-1_AB461855_Japanese_anberjack_Japan RSIV-U-6_AB461856_red_sea_bream Japan RBIV-CNU-2_AY849394_barred_knifejaw_Korea KGIV-Pt96-06_JF264355 giant grouper_Taiwan RSIV-1_AB666328_barred_knifejaw_Japan RSIV-4_AB666331_striped_jack_Japan RSIV-6SB_AB666327_yellowfin_sea_bream_Hong_Kong RSIV-7_AB666334 red sea bream Japan

CPIV-05_EU847420_common_pony_fish_Taiwan

C RBIV-KOR-TY1_AY532606_barred_knifejaw_Korea GSDIV_AY285746_Malabar_grouper_Thailand 00 GSDIV2_AB109370_Malabar_grouper_Thailan [SBIV_AY310917_sea_bass_South_China_sea

$I_{\text {SBIV2 }}$ AB109372 sea bass South China sea 97_ISKNV-XQ_HQ317457_Chinese_perch_China LISKNV-XT_HQ317457_Chinese_perch_China [LYCIV_AY779031_large_yellow_croaker_China 100 RSIV-Ehime1_AB080362_red_sea_bream_Japan RSIV-2HSB_AB666318_hybrid_of_sea_bass_Hong_Kong MGIV-Nt-546-09 JF264348 marble goby Taiwan SSIV-05_EU847419_silver_sea_bream_Taiwan RSIV-TGA12_AB666319_brown_marbled_grouper_Singapore 94 OBIV_Orbiculate_batfish_Indonesia/PkIV*

MSGIV_HM067835_marble_sleepy_goby_China DGIV2 AB109369 dwarf gourami Malaysia

-ALIV_AB109368_African_lampeye_Indonesia ALIV2_AY285745_African_lampeye_Indonesia [GSIV-Pt-843-05_JF264354_giant_sea_perch_Taiwan SSBIV-Pt-703-05 JF264356 silver_sea bream Taiwan GSIV-Pt-836-05 JF264350 giant sea perch Taiwan TGIV-Pt-141-06_JF264345 orange-spotted grouper_Taiwan TGIV-Pt-308-08_JF264349_orange-spotted_grouper_Taiwan ISKNV-1GG_AB666340_orange-spotted_grouper_Hong_Kong ISKNV-9GG_AB666341_orange-spotted_grouper_Hong_Kong ISKNV-DG128_AB666348_dwarf_gourami_Singapore ISKNV-DG810_AB666347 dwarf gourami Singapore ISKNV-DGA136_AB666345_dwarf_gourami_Singapore ISKNV_AF371960_Chinese_perch_China ISKNV2_AF370008_Chinese_perch_China ISKNV-DW HQ317465 Chinese perch China ISKNV-HZhm HQ317462 Chinese perch_China ISKNV-NZh_HO317461 Chinese perch China ISKNV-NZh_HQ317461_Chinese_perch_China ISKNV-lapulapu_AB666339_orange-spotted_grouper_Philippine ISKNV-MA16_AB666342_flathead-mullet_Singapore ISKNV-MA55_AB666343_flathead-mullet_Singapore ISKNV-reddrum_AB666337 reddrum_Malaysia ISKNV-seabass AB666338 barramundi perch Malaysia DGIV3_AY989901_dwarf_gourami_Australia ISKNV-DGA108_AB666346_dwarf_gourami_Singapore MCIV AY936203 murray cod Australia

- ISKNV-DGA46K AB666344 dwarf gourami Singapore COFLIV-1_EU276417_bastard halibut_Korea

ISKNV-OY HO317460 Chinese perch China

FLIV-JJ_A Y 633988 _ bastard_hatibut_Korea

'LFIV_AY661546_bastard_halibut_Korea

86_TRBIV_AY590687_turbot_China

TRBIV2 GO273492 turbot_Chit

SPIV-CH-1 HM067603 sea perch Kore

- RBIV-KOR-CS AY532611 barred knifejaw Korea

PIV-6032China_HQ263621_perch_China

SFIV-6033China_HQ2636.22_perch_China

TIV-R-603_HM596017 turbot_China
Clade 2

RSIV

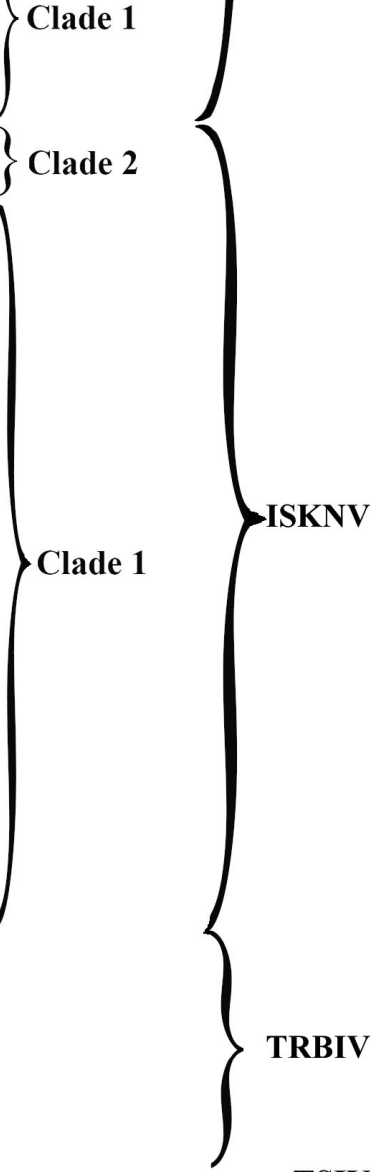

TSIV 


\section{DISCUSSION}

This study adds to the growing literature on the emerging threat of megalocytiviruses to the international ornamental fish trade (Armstrong \& Ferguson 1989, Anderson et al. 1993, Rodger et al. 1997, Sudthongkong et al. 2002, Weber et al. 2009, Kim et al. 2010, Yanong \& Waltzek 2010). Here we present the first case of a megalocytivirus outbreak in orbiculate batfish based on histologic, ultrastructural, and genetic evidence. Infected cytomegalic cells displayed basophilic granular intracytoplasmic inclusions in various tissues, similar to descriptions in previous reports, including the report of megalocytivirus infection in Banggai cardinalfish (Gibson-Kueh et al. 2003, Weber et al. 2009, Yanong \& Waltzek 2010, Zhang et al. 2011, Waltzek et al. 2012). The size, icosahedral shape, and intracytoplasmic location of virions is also consistent with reports of megalocytivirus infections in tropical freshwater and marine ornamental fishes, including Banggai cardinalfish (Paperna et al. 2001, Sudthongkong et al. 2002, Gibson-Kueh et al. 2003, Weber et al. 2009).

The OBIV full-length MCP sequence was found to be identical to the only other megalocytivirus reported from a marine ornamental fish species, the Banggai cardinalfish iridovirus (Weber et al. 2009). Interestingly, concurrent with the orbiculate batfish mortality event, recently imported wild Banggai cardinalfish that had been kept at the same quarantine facility in the UK also died after delivery to another public aquarium in Denmark. Those fish were found to be positive for BCIV by histopathology and PCR (M. F. Stidworthy \& T. B. Waltzek unpubl. data). Taken together with the genetic evidence, these data suggest that OBIV and BCIV are the same virus. This agent may be capable of infecting other species, similar to what has been reported for other megalocytivirus species (Kurita \& Nakajima 2012).

It cannot be determined whether the imported wild orbiculate batfish and Banggai cardinalfish spread the virus to each other following importation into the UK or whether these species had already acquired the virus in the wild or at the export facilities. Although the Banggai cardinalfish is restricted to a small region in Indonesia known as the Banggai archipelago, the orbiculate batfish occurs sympatrically, and both species are sometimes cultured on the same Indonesian ornamental fish farms for sale in international ornamental fish markets (T. B. Waltzek pers. obs.). Future surveillance efforts are needed to determine where marine ornamental fishes become infected with megalocytiviruses as well as to assess the overall impact on international trade (e.g. frequency of epizootics and number of susceptible species).

Acknowledgements. M. Potin, T. Defonseca, R. James, G. Adamson, J. F. Wellehan, and L. Archer provided technical assistance. We thank A. S. Kane and J. E. Hill for their constructive criticism of the manuscript.

\section{LITERATURE CITED}

Ahne W, Bremont M, Hedrick RP, Hyatt AD, Whittington RJ (1997) Special topic review: iridoviruses associated with epizootic haematopoietic necrosis (EHN) in aquaculture. World J Microbiol Biotechnol 13:367-373

Altschul SF, Madden TL, Schäffer AA, Zhang J, Zhang Z, Miller W, Lipman DJ (1997) Gapped BLAST and PSIBLAST: a new generation of protein database search programs. Nucleic Acids Res 25:3389-3402

- Anderson IG, Prior HC, Rodwell BJ, Harris GO (1993) Iridovirus-like virions in imported dwarf gourami (Colisa lalia) with systemic amoebiasis. Aust Vet J 70:66-67

> Armstrong RD, Ferguson HW (1989) Systemic viral disease of the chromide cichlid Etropus maculates. Dis Aquat Org 7:155-157

Capuli EE, Ortanez AK (2011) Platax orbicularis. Available at www.fishbase.org/summary/Platax-orbicularis.html

$>$ Chen XH, Lin KB, Wang XW (2003) Outbreaks of an iridovirus disease in maricultured large yellow croaker, Larimichthys crocea (Richardson), in China. J Fish Dis 26:615-619

Chinchar VG, Hyatt A, Miyazaki T, William T (2009) Family Iridoviridae: poor viral relation no longer. Curr Top Microbiol Immunol 328:123-170

David R, Tréguier C, Montagnani C, Belliard C, and others (2010) Molecular detection of betanodavirus from the farmed fish, Platax orbicularis (Forsskal) (Ephippidae), in French Polynesia. J Fish Dis 33:451-454

Fraser WA, Keefe TJ, Bolon B (1993) Isolation of an iridovirus from farm-raised gouramis (Trichogaster trichopterus) with fatal disease. J Vet Diagn Invest 5:250-253

> Gibson-Kueh S, Netto P, Ngoh-Lim GH, Chang SF, and others (2003) The pathology of systemic iridoviral disease in fish. J Comp Pathol 129:111-119

> Gibson-Kueh S, Ngoh-Lim GH, Netto P, Kurita J, Nakajima $\mathrm{K}, \mathrm{Ng}$ ML (2004) A systemic iridoviral disease in mullet, Mugil cephalus L., and tiger grouper Epinephelus fuscoguttatus Forsskal: a first report and study. J Fish Dis 27: 693-699

> Go J, Whittington R (2006) Experimental transmission and virulence of a megalocytivirus (Family Iridoviridae) of dwarf gourami (Colisa lalia) from Asia in Murray cod (Maccullochella peelii peelii) in Australia. Aquaculture 258:140-149

> Guindon S, Gascuel O (2003) A simple, fast and accurate method to estimate large phylogenies by maximumlikelihood. Syst Biol 52:696-704

Hayat MA (1989) Principles and techniques of electron microscopy: biological applications. CRC Press, Boca Raton, FL

> He JG, Wang SP, Zeng K, Huang ZJ, Chan SM (2000) Systemic disease caused by an iridovirus-like agent in cultured mandarinfish, Siniperca chuatsi (Basilewsky), in China. J Fish Dis 23:219-222

> He JG, Zeng K, Weng SP, Chan SM (2002) Experimental 
transmission, pathogenicity and physical-chemical properties of infectious spleen and kidney necrosis virus (ISKNV). Aquaculture 204:11-24

Inouye K, Yamano K, Maeno Y, Nakajima K, Matsuoka M, Wada Y, Sorimachi M (1992) Iridovirus infection of cultured red sea bream, Pagus major. Fish Pathol 27:19-27

Jeong JB, Cho HJ, Jun LJ, Hong SH, Chung JK, Jeong HD (2008a) Transmission of iridovirus from freshwater ornamental fish (pearl gourami) to marine fish (rock bream). Dis Aquat Org 82:27-36

Jeong JB, Kim HY, Jun LJ, Lyu JH, Park NG, Kim JK, Jeong HD (2008b) Outbreaks and risks of infectious spleen and kidney necrosis virus disease in freshwater ornamental fishes. Dis Aquat Org 78:209-215

> Johannessen JV (1977) Use of paraffin material for electron microscopy. Pathol Annu 12:189-224

> Jung SJ, Oh MJ (2000) Iridovirus-like infection associated with high mortalities of striped beakberch, Oplegnathus fasciatus (Temminck et Schlegel), in southern coastal areas of the Korean peninsula. J Fish Dis 23:223-226

Katoh K, Kuma K, Toh H, Miyata T (2005) MAFFT version 5: improvement in accuracy of multiple sequence alignment. Nucleic Acids Res 33:511-518

Kawakami H, Nakajima K (2002) Cultured fish species affected by red sea bream iridoviral disease from 1996 to 2000. Fish Pathol 37:45-47

Kim WS, Oh MJ, Kim JO, Kim D, Jeon CH, Kim JH (2010) Detection of megalocytivirus from imported tropical ornamental fish, paradise fish Macropodus opercularis. Dis Aquat Org 90:235-239

Kurita J, Nakajima K (2012) Megalocytiviruses. Viruses 4: 521-538

Lawler AR, Ogle GT, Donnes C (1978) New hosts for lymphocystis. Gulf Res Rep 6:183-184

Paperna I, Vilenkin M, Alves de Matos AP (2001) Iridovirus infections in farm-reared tropical ornamental fish. Dis Aquat Org 48:17-25

Posada D (2008) jModelTest: phylogenetic model averaging. Mol Biol Evol 25:1253-1256

Rodger H, Kobs M, Macartney A, Frerichs GN (1997) Systemic iridovirus infection in freshwater angelfish, Pterophyllum scalare (Lichtenstein). J Fish Dis 20:69-72

Editorial responsibility: V. Gregory Chinchar,

Jackson, Mississippi, USA
Shi CY, Wang YG, Yang SL, Huang J, Wang QY (2004) The first report of an iridovirus-like agent infection in farmed turbot, Scophthalmus maximus, in China. Aquaculture 236:11-25

Sudthongkong C, Miyata M, Miyazaki T (2002) Iridovirus disease in two ornamental tropical fishes: African lampeye and dwarf gourami. Dis Aquat Org 48:163-173

> Tamura K, Peterson D, Peterson N, Stecher G, Nei M, Kumar S (2011) MEGA5: molecular evolutionary genetics analysis using maximum likelihood, evolutionary distance, and maximum parsimony methods. Mol Biol Evol 28: 2731-2739

> Thompson JD, Higgins DG, Gibson TJ (1994) CLUSTAL W: improving the sensitivity of progressive multiple sequence alignment through sequence weighting, position-specific gap penalties and weight matrix choice. Nucleic Acids Res 22:4673-4680

- Waltzek TB, Marty GD, Alfaro ME, Bennett WR and others (2012) Systemic iridovirus from threespine stickleback Gasterosteus aculeatus represents a new megalocytivirus species (family Iridoviridae). Dis Aquat Org 98: $41-56$

> Wang CS, Shih HH, Ku CC, Chen SN (2003) Studies on epizootic iridovirus infection among red sea bream, Pagrus major (Temminck \& Schlegel), cultured in Taiwan. J Fish Dis 26:127-133

- Wang Q, Zeng WW, Li KB, Chang OQ, and others (2011) Outbreaks of an iridovirus in marbled sleepy goby, Oxyeleotris marmoratus (Bleeker), cultured in southern China. J Fish Dis 34:399-402

Weber ES, Waltzek TB, Young DA, Twitchell EL, and others (2009) Systemic iridovirus infection in the Banggai cardinalfish (Pterapogon kauderni Koumans 1933). J Vet Diagn Invest 21:306-320

Yanong RPE, Waltzek TB (2010) Megalocytivirus infections in fish, with emphasis on ornamental species. University of Florida IFAS Cooperation Extensive Service, Circular FA-182. Available at http://edis.ifas.ufl.edu/fa182

Zhang M, Xiao ZZ, Hu YH, Sun L (2011) Characterization of a megalocytivirus from cultured rock bream, Oplegnathus fasciatus (Temminck \& Schlege), in China. Aquacult Res 43:554-564

Submitted: January 2, 2013; Accepted: March 4, 2013 Proofs received from author(s): June 11, 2013 